Article

\title{
Organic Farming Practices and Shade Trees Reduce Pest Infestations in Robusta Coffee Systems in Amazonia
}

\author{
Kevin Piato ${ }^{1,2, * \mathbb{C}}$, Cristian Subía $^{3}$, Jimmy Pico ${ }^{3}$, Darío Calderón ${ }^{3}$, Lindsey Norgrove ${ }^{2}$ and François Lefort ${ }^{1, * \mathbb{D}}$ \\ 1 Plants and Pathogens Group, Research Institute Land Nature and Environment, Geneva School of \\ Engineering, Architecture and Landscape (HEPIA), HES-SO University of Applied Sciences and Arts Western \\ Switzerland, 1254 Jussy, Switzerland \\ 2 School of Agricultural, Forest and Food Sciences (HAFL), Bern University of Applied Sciences (BFH), \\ 3052 Zollikofen, Switzerland; lindsey.norgrove@bfh.ch \\ 3 National Institute of Agronomical Research (INIAP)-Central Experimental Station of Amazonia, km 3 Vía \\ Sacha-San Carlos, Cantoón, La Joya de los Sachas 220350, Ecuador; cristian.subia@iniap.gob.ec (C.S.); \\ jimy.pico@iniap.gob.ec (J.P.); dario.calderon@iniap.gob.ec (D.C.) \\ * Correspondence: kevin.piato@students.bfh.ch (K.P.); francois.lefort@hesge.ch (F.L.)
}

Citation: Piato, K.; Subía, C.; Pico, J.; Calderón, D.; Norgrove, L.; Lefort, F. Organic Farming Practices and Shade Trees Reduce Pest Infestations in Robusta Coffee Systems in Amazonia. Life 2021, 11, 413. https://doi.org/ 10.3390/life11050413

Academic Editors: Balazs Barna and Gustavo Caetano-Anolles

Received: 23 February 2021

Accepted: 28 April 2021

Published: 30 April 2021

Publisher's Note: MDPI stays neutral with regard to jurisdictional claims in published maps and institutional affiliations.

Copyright: () 2021 by the authors. Licensee MDPI, Basel, Switzerland. This article is an open access article distributed under the terms and conditions of the Creative Commons Attribution (CC BY) license (https:// creativecommons.org/licenses/by/ $4.0 /)$.
Abstract: Coffee agroforestry systems could reconcile agricultural and environmental objectives. While pests and diseases can reduce yield, their interactions with shade and nutrition have been rarely researched, and are particularly lacking in perennial systems. We hypothesized that intermediate shade levels could reduce coffee pests while excess shade could favor fungal diseases. We hypothesized that organic rather than mineral fertilization would better synchronize with nutrient uptake and higher nutrient inputs would be associated with reduced pest and disease damage due to higher plant vigor, yet effects would be less obvious in shaded plots as coffee growth would be lightlimited. Using three-year-old trees of Coffea canephora var. Robusta (robusta coffee) in the Ecuadorian Amazon, we compared a full-sun system with four shading methods creating different shade levels: (1) Myroxylon balsamum; (2) Inga edulis; (3) Erythrina spp.; or, (4) Erythrina spp. plus Myroxylon balsamum. Conventional farming at either (1) moderate or (2) intensified input and organic farming at (3) low or (4) intensified input were compared in a split-plot design with shade as the main plot factor and farming practice as the sub-plot factor. The infestation of the following pests and disease incidences were evaluated monthly during the dry season: brown twig beetle (Xylosandrus morigerus), coffee leaf miner (Leucoptera coffeella), coffee berry borer (Hypothenemus hampei), anthracnose disease (Colletotrichum spp.), thread blight (Pellicularia koleroga), and cercospora leaf spot (Cercospora coffeicola). Coffee berry borer and brown twig beetle infestation were both reduced by $7 \%$ in intensified organic treatments compared to intensified conventional treatments. Colonization of coffee berry borer holes in coffee berries by the entomopathogenic fungus Beauveria bassiana was also assessed. Brown twig beetle infestation was significantly higher under full sun than under Inga edulis, yet no other shade effects were detected. We demonstrate for the first time how intensified input use might promote pest populations and thus ultimately lead to robusta coffee yield losses.

Keywords: Coffea canephora; biocontrol; agroforestry

\section{Introduction}

Current global coffee productivity is threatened by both climate change [1-3] and a high price volatility, affecting approximately 17 million coffee farmers, mainly smallholders, worldwide [4-6]. Climate change might favor the outbreak of pests and diseases [7], making coffee growers more dependent on external inputs. The trend towards full-sun coffee might also increase reliance on external inputs, although both Coffea canephora Pierre ex. A. Froehner and C. arabica L. can grow under shade [8]. Greater use of fungicides and insecticides might also increase secondary pest problems due to their impacts on beneficial natural enemies, whether insect predators or entomopathogens [9]. Shade-grown coffee 
crops might be more sustainable $[10,11]$ and might better reconcile agricultural, social, and environmental goals [12].

The total daily assimilation rate of a coffee tree is greater in the shade than in the sun $[13,14]$. Shade tree inclusion also modifies the microclimate in coffee fields $[15,16]$. Barradas and Fanjul [17] found that the average maximum temperature in a coffee plantation in Mexico was reduced by more than $5{ }^{\circ} \mathrm{C}$, compared to unshaded coffee, consequently reducing the vapor pressure deficit. Shade tree inclusion can modify air movement and wind in the understory [18]. A recent meta-analysis on the impact of shade trees on robusta coffee showed that shade trees may enhance yield, growth, and biodiversity, yet few studies tested the effects on pests and diseases to allow a general judgment to be made [19]. Arabica and robusta coffee trees do not have the same ecology [20] and recommended fertilizer rates vary [21], which might alter the shade response [10,18,22-24], and the type of shade trees used [25]. Furthermore, C. arabica and C. canephora may not have the same sensitivity to pests and diseases [26]. Disease incidence can also be modified by soil fertility and by fertilizer inputs. For example, Silva et al. [27] showed that soil P and K correlated positively with coffee leaf rust incidence whereas Ca correlated negatively. Avelino et al. [28] considered that fertilization would modify berry load and leaf area of coffee, and this would in turn modify the coffee risk infection cycle. Staver et al. [9] summarized effects of shade in arabica plantations on various pest and diseases species stating that cercospora had a strongly negative response to shade whereas other fungal pathogens were not affected or had erratic responses. There are few studies available on other coffee diseases. Research is needed to determine if shade provides any pest and disease control and to assess how it interacts with crop management to develop best-bet robusta coffee systems [29].

Ecuador produces both arabica and robusta coffee and is in the top 20 world producers of coffee. However, production has been decreasing from 90,000 metric tons per year in 1991 to 37,000 metric tons in 2018 [30]. In the Ecuadorian Amazon Region (EAR), more than $60 \%$ of farmers cultivate coffee, although production is constrained by unsuitable soils, pests and disease losses, and the lack of education and training for farmers [31]. According to Nieto and Caicedo [31], pests and diseases reduce coffee yield by $30 \%$ to $40 \%$ in the EAR.

In our study, we used three tree species as shade providers: Myroxylon balsamum L. (MB), Erythrina spp. (ES), and Inga edulis Mart. (IE) either alone or in combination, as well as the herbaceous Musa spp. AAB (plantain) in all coffee plots. IE produces edible fruit and wood [32]. Tree polycultures might have fewer pest outbreaks and retain more natural enemies [33] but cannot eliminate pest and disease outbreaks [16], as these occur even in highly diverse natural vegetation [34]. Plantain grows fast and provides additional income before the coffee yield is realized. The deciduous fast-growing tree MB of the Fabaceae family is common in tropical forests between $200 \mathrm{~m}$ a.s.l. and $690 \mathrm{~m}$ a.s.l. [35] but not in the EAR [36]. Nevertheless, its presence could provide an additional amount of notable income because its resin is widely used by the cosmetics and pharmaceutical industry [37]. ES (Fabaceae), an evergreen legume pantropical tree, is widely used throughout the world as a shelter tree, especially in cocoa agroforestry systems [38]. Here we chose to combine $\mathrm{MB}$ and ES, an evergreen with a deciduous tree to have constant shade throughout the year, which might improve coffee quality [39].

We aimed to assess pests and diseases under different agroforestry systems and intensive versus organic farming practices at different input levels. We hypothesized that intermediate shade levels, where coffee growth is optimized, could reduce coffee pests while too much shade could favor fungal diseases. We hypothesized that higher nutrient inputs would be associated with reduced pest and disease development due to higher plant vigor and that organic rather than mineral fertilization would lead to further benefits due to the slower nutrient release rates. We hypothesized that any positive effect of nutrients would be less obvious in plots with higher shade levels given that plant growth would be light-limited. Shade level was not expected to be high because all trees were not fully developed. We also estimated shade level in each treatment in order to discriminate 
between the shading effect of a tree and its specific species interaction with pests and diseases (Figure 1).

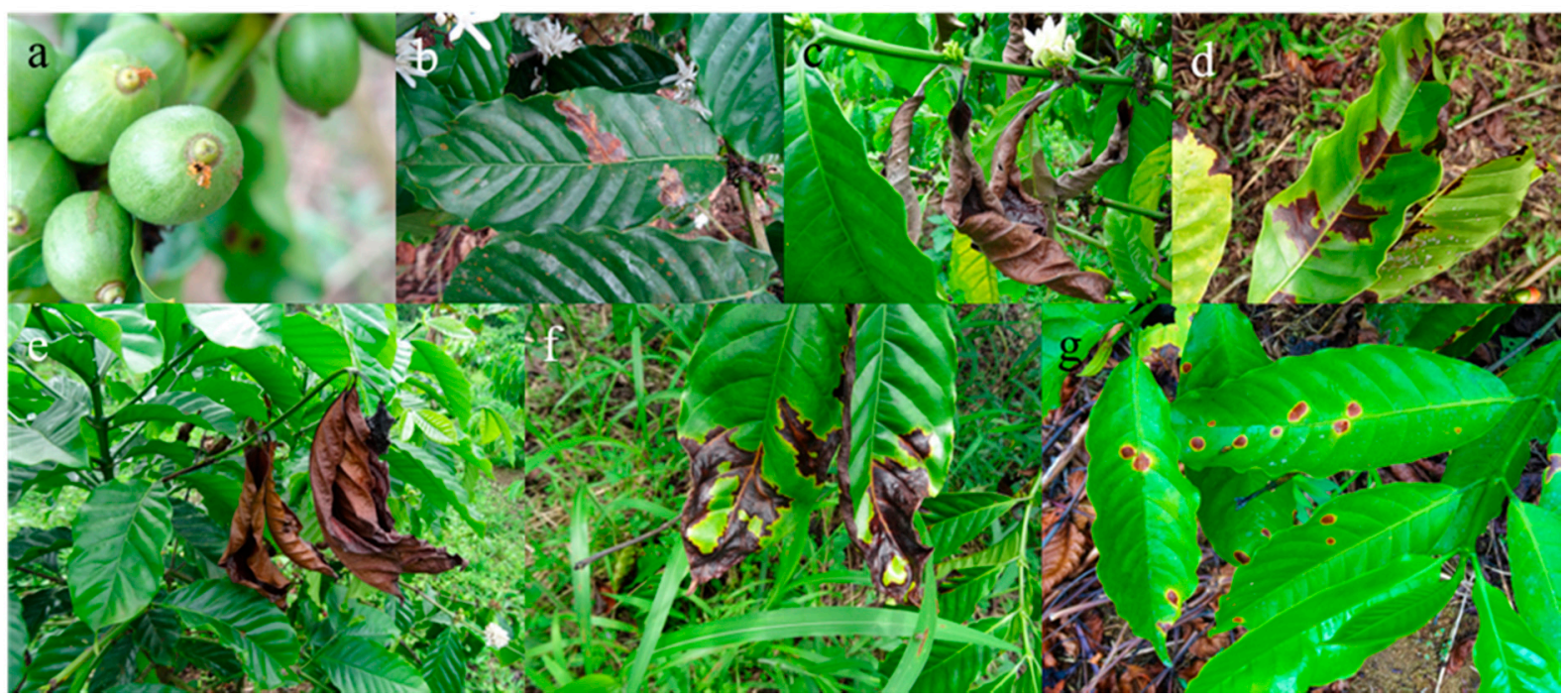

Figure 1. Pests and fungi affecting Coffea canephora var. Robusta plants in the Ecuadorian Amazonia (@ Kevin Piato): (a) Hypothenemus hampei, (b) Leucoptera coffeella, (c) Pellicularia koleroga, (d) Phoma spp., (e) Xylosandrus morigerus, (f) Colletotrichum spp., and (g) Cercospora coffeicola.

\section{Materials and Methods}

\subsection{Site Description}

This study was conducted from July-September 2018 in La Joya de los Sachas in the province of Orellana in Ecuador (latitude $00^{\circ} 21^{\prime} 31.2^{\prime \prime} \mathrm{S}$, longitude $76^{\circ} 52^{\prime} 40.1^{\prime \prime} \mathrm{W}$ ) at the INIAP's Amazonian Central Station (EECA). The climate is classified as Af (tropical rainforest climate) according to the Köppen-Geiger climate classification [40]. Based on 37 years of data, the average annual precipitation is between 3000 and $3500 \mathrm{~mm}$ in the region of La Joya de los Sachas [41], and the average annual temperature is between $26^{\circ} \mathrm{C}$ and $27^{\circ} \mathrm{C}$ [42] with an elevation of $250 \mathrm{~m}$ above sea level (a.s.1.). Meteorological data during the study is shown in Table 1. In 2018, the dry season began in August 2018, with lower relative humidity (RH), rainfall, and higher temperature. Soil is classified as an Andic Dystrudepts with $43 \%$ of clay, $27 \%$ of silt, and $30 \%$ of sand [43]. Vegetation is humid, moist forest [44]. The year 2018 was representative in terms of rainfall and temperature when compared to the previous 8 years. In 2018 , a mean max temperature of $30.66{ }^{\circ} \mathrm{C}$, min temperature of $22.56{ }^{\circ} \mathrm{C}$, and total annual rainfall of $2955 \mathrm{~mm}$ were recorded in La Joya de los Sachas [45] which are close, respectively, to the mean max temperature of $30.58{ }^{\circ} \mathrm{C}$, min temperature of $20.33{ }^{\circ} \mathrm{C}$, and rainfall of $3050 \mathrm{~mm}$ per year [46] from 2010 to 2017 (Figures S1-S3).

Table 1. Mean maximum, minimum temperatures, total rainfall, and mean relative humidity (RH) per month at $07 \mathrm{~h}, 13 \mathrm{~h}$, and $19 \mathrm{~h}$ at La Joya de los Sachas meteorological station, Ecuador [45].

\begin{tabular}{ccccccc}
\hline Month & $\begin{array}{c}\text { Mean Max } \\
\text { Temp. }\left({ }^{\circ} \mathbf{C}\right)\end{array}$ & $\begin{array}{c}\text { Mean Min } \\
\text { Temp. }\left({ }^{\circ} \mathbf{C}\right)\end{array}$ & $\begin{array}{c}\text { Total Rainfall } \\
(\mathbf{m m})\end{array}$ & $\begin{array}{c}\text { Mean RH at } \\
\mathbf{7} \text { am (\%) }\end{array}$ & $\begin{array}{c}\text { Mean RH at } \\
\mathbf{1} \mathbf{~ p m ~ ( \% )}\end{array}$ & $\begin{array}{c}\text { Mean RH at } \\
\mathbf{7} \mathbf{~ p m} \mathbf{( \% )}\end{array}$ \\
\hline April 18 & 30.1 & 20.8 & 299.0 & 95 & 80 & 85 \\
May 18 & 30.2 & 22.0 & 358.9 & 90 & 80 & 80 \\
June 18 & 29.5 & 21.8 & 193.5 & 95 & 80 & 85 \\
July 18 & 30.3 & 21.4 & 212.9 & 90 & 90 & 80 \\
August 18 & 30.7 & 21.7 & 150.7 & 90 & 80 \\
September 18 & 32.1 & 22.2 & 114.6 & 90 & & 80 \\
\hline
\end{tabular}




\subsection{Experimental Design}

The experiment had a split-plot design $(n=3)$ with agroforestry treatment as the main-plot factor and farming practice (fertilization and weeding) treatment as the sub-plot factor. The main plot size was $120 \mathrm{~m} \times 36 \mathrm{~m}$, divided into 4 sub-plots, each $30 \mathrm{~m} \times 36 \mathrm{~m}$. The previous land use was a 9-year-old palm oil plantation and was cleared in 2015. For the shade assessments, we did not consider differences between the sub-plot factors so the data were analyzed as a randomized complete block design ( $R C B D, n=4)$.

On 20th November 2015, Coffea canephora var. Robusta plants of the NP-3013 and NP2024 clones were planted in all plots at 1333 plants per hectare $(3 \mathrm{~m} \times 2.5 \mathrm{~m}$ spacing) with $100 \mathrm{~g}$ of fertilizer (10:30:10) applied by hand on the ground near the stem. These cultivars are not susceptible to the coffee leaf rust pathogen Hemilia vastatrix. Different shade treatments were then added to the coffee plots: Myroxylon balsamum and Musa spp. (TIM), where MB was at 83 stems per hectare (10 $\mathrm{m} \times 12 \mathrm{~m}$ spacing); Erythrina spp. and Musa spp. (ERY), where ES was at 333 stems per hectare ( $5 \mathrm{~m} \times 6 \mathrm{~m}$ spacing); Inga edulis and Musa spp. (GUA), where IE was at 83 stems per hectare (10 $\mathrm{m} \times 12 \mathrm{~m}$ spacing); and Myroxylon balsamum, Erythrina spp., and Musa spp. (TaE), with both MB and ES trees at a total density of 83 stems per hectare and planted alternately. The fifth treatment was a full sun system without trees (SUN). All treatments, except SUN, also contained Musa spp. AAB plants as temporary shade at 333 plants per hectare $(5 \mathrm{~m} \times 6 \mathrm{~m}$ spacing). IE trees were replanted on 24.07.2017 due to poor growth, so they were one year old when the field assessments were performed.

Four farming practices, varying in their fertilizer amounts, types, and weeding were compared as sub-plot treatments: intensive conventional (IC); moderate conventional (MC); intensive organic (IO); and low organic (LO). In IC and $\mathrm{MC}$ farming practices, the fertilizer amounts applied in week 20 of 2018 were: $34 \mathrm{~kg} / \mathrm{ha}$ of $\mathrm{KNO}_{3}, 41 \mathrm{~kg} / \mathrm{ha}$ of $\mathrm{KH}_{2} \mathrm{PO}_{4}$, $51 \mathrm{~kg} / \mathrm{ha}$ of YaraMila Actyva 20-7-10-2MgO-10SO $3,123 \mathrm{~kg} / \mathrm{ha}$ of YaraMila Hydran 19-4-19$3 \mathrm{MgO}$, and $41 \mathrm{~kg} / \mathrm{ha}$ of $\mathrm{NH}_{4} \mathrm{NO}_{3}$. This corresponded to $225 \mathrm{~g}$ of chemical fertilizer per coffee plant. In IO and LO farming practices, $1334 \mathrm{~kg} / \mathrm{ha}$ of Eco Abonaza India 3.5-2-3.5 (a mix of semi-composted chicken manure and sawdust with a content of $70-73 \%$ of organic matter) were applied in week 9 of the year 2018. This corresponded to $1000 \mathrm{~g}$ of organic fertilizer per coffee plant. In all farming practices, fertilizer was applied to the side of the coffee plant by hand.

Farming practices also differed in the type and frequency of weeding. Weeds were controlled by means of herbicides, with 4 applications per year in IC plots against 2.5 in MC plots. Furthermore, mechanical weeding with brush-cutters was done, with respectively 4 , 4,5 , and 4 interventions in IC, MC, IO, and LO plots (Table S1). All mechanical weeding was done with a string strimmer and residue was left in place.

\subsection{Pest and Disease Sampling}

Incidences of the following were evaluated monthly on coffee: the brown twig beetle, Xylosandrus morigerus (BTB); the coffee leaf miner, Leucoptera coffeella (CLM); the coffee berry borer, Hypothenemus hampei (CBB); anthracnose disease, Colletotrichum spp. (AD); thread blight, Pellicularia koleroga (TB); cercospora leaf spot, Cercospora coffeicola (CLS); and phoma leaf spot, Phoma spp. (PLS). Furthermore, AD severity was assessed on fruits damaged by CBB. Finally, the presence of the entomopathogen Beauveria bassiana (BB) was detected by the presence of white mycelium covering the holes made by CBB. All pest and disease assessments were made on the 36 central square coffee plants only $(6 \times 6$ plants $)$ per subplot. Nine plants were randomly selected from the central area, per plot, across the various shade zones. Thus, 540 plants were assessed in the 60 plots. As the focus of the study was on coffee pests and diseases, we did not make such measurements on the shade trees.

The following symptoms were used to discriminate between diseases and pests tested: necrotic brown-black lesions in the margin of the leaf with a dry appearance for AD; malformation of young leaves with brown spot with a shiny appearance for PLS; circular 
small brown spots with a center tan to light brown for CLS; overleaf blackening and rotting leading to leaf detachment which remains attached through fungal strand for TB; presence of a hole near the apex of the fruit, sometimes with sawdust around it for CBB; presence of leaf lesions between the epidermis showing two visible layers for CLM; presence of twig necrosis with one or several holes for BTB $[8,47]$.

We measured all variables on 12-13 July 2018, 13-14 August 2018, and 3 September 2018 (except irradiation measurements that were made once), and AD severity was assessed on 12-13 July 2018 only. For each robusta coffee plant selected, 3 branches were randomly selected at $<50 \mathrm{~cm}, 50-100 \mathrm{~cm}$, and $>100 \mathrm{~cm}$ height. The short internode was identified in each branch to distinguish between the current year's leaves and those of the previous year. All healthy leaves from the short internode to the branch tip of the branch were counted. Leaves infected by AD, PLS, CLS, TB, and infested by CLM were also counted by section. We sampled two leaves per branch (those after the short internode) to determine AD severity, for a total of 6 leaves per plant (according to [48]). This method was used as older leaves are more likely to be infested and infected, senescing more easily than younger ones. All branches on one coffee stem were counted, as well as all branches with BTB damage. Moreover, all the fruit on two other branches randomly selected at $<50 \mathrm{~cm}$ and 50-100 cm height but displaying enough fruit were counted: one from the low section and one from the middle section. Then all the fruit showing a CBB hole and BB presence were counted.

\subsection{Shade Estimates and Solar Radiation Measurements}

Total irradiation measurements above coffee plants were made with an Apogee MP200 silicon-cell pyranometer with a separate sensor and a levelling plate. Shade was defined as the quantity of total solar radiation in $\mathrm{W} / \mathrm{m}^{2}$ that cannot reach the coffee plants since it is absorbed or reflected by the overstory trees. Shade measurements were made only in one block due to time limitations. Solar radiation was measured in the central part of the plot, comprising $6 \times 6$ coffee plants, to avoid edge effects. For each of the shade types, except for the SUN, zones between shade trees were defined (Table S2) to take account of heterogeneous shade distribution within the plot. Solar radiation was measured with a pyranometer on 1 randomly selected coffee plant per zone (Table S2), except for the SUN shade type, in which 2 coffee plants were randomly selected. As 18 zones were defined, 76 coffee plants were assessed in total to work out the shade percentage for each zone $(4 \times$ 19 coffee plants).

For each selected coffee plant, 5 measurements of solar radiation were made with the pyranometer: at the apex, the east, west, north, and south of the plant. A reference was also taken in SUN. To avoid interference of self-shading coffee bushes [49], measurements were done at the tip of the branches and at $2 \mathrm{~m}$ height. Pyranometer measurements were taken in full sunlight. Measurements were done at 0900h-1030h, 1130h-1300h, and 1400h-1530h.

\subsection{Determination of Colletotrichum spp. Severity by Image Processing}

Leaves collected (3240) were scanned with the multi-function printers EPSON L555 Series and Hewlett-Packard HP Color Laser Jet CM1312 MFP at a resolution of 200 dpi. Images were processed with "ImageJ 1.52a" [50] to determine total leaf area and the total leaf necrotic area. To determine the leaf area damaged by AD only, the following filter of the function "Adjust color balance" was used: Lab-white, $L^{*}=7-95 / a^{*}=124-243 / b^{*}=0-255$. Only necrotic areas larger than 500 pixels were considered.

\subsection{Data Processing \\ 2.6.1. Data Quality Control}

Only the total numbers of branches, fruits, and leaves between the 10th and 90th percentile were considered, but not outliers. For mean values of infestation, incidence, and presence rates, only values between 5th and 95th percentiles were considered, and outliers were deleted. These last two steps were also necessary to exclude errors due to the 
misidentification of the short internode and the bias of selectors taking branches with few fruits to gain time. Data quality control to remove outliers was performed for all variables except AD severity. For AD severity rate, rates between the 1st and 99th percentiles were taken into consideration, and all other values deleted to exclude leaves damaged after the harvest or picked below the short internode.

\subsubsection{Calculations}

Formula used to calculate all the response variables (except the shading percentage) are outlined in Table 2.

Table 2. Formulae for pest, disease, and growth variables.

\begin{tabular}{|c|c|c|c|}
\hline $\begin{array}{c}\text { Response } \\
\text { Variables (\%) }\end{array}$ & Variables & Meaning & Formula \\
\hline \multirow{2}{*}{ CBB inf. ${ }^{1}$} & $n^{\prime}$ & Number of cherries where CBB was present & \multirow{2}{*}{$\left(n^{\prime} / N^{\prime}\right) \times 100$} \\
\hline & $N^{\prime}$ & Total number of cherries assessed & \\
\hline AD inc. ${ }^{2}$ & \multirow{2}{*}{$N$} & \multirow{2}{*}{ Number of infected leaves } & \multirow{4}{*}{$(n / N) \times 100$} \\
\hline PLS inc. & & & \\
\hline CLS inc. & \multirow{2}{*}{$N$} & \multirow{2}{*}{ Total number of leaves } & \\
\hline TB inc. & & & \\
\hline BTB inf. & $R$ & Number of branches where BTB was present & \multirow{2}{*}{$(r / R) \times 100$} \\
\hline CLM inf. & $R$ & Total number of branches assessed & \\
\hline \multirow{2}{*}{ AD sev. ${ }^{3}$} & $S$ & Total necrotic area of leaves & \multirow{2}{*}{$(s / S) \times 100$} \\
\hline & $S$ & Total area of leaves & \\
\hline \multirow{2}{*}{ BB pres. ${ }^{4}$} & $B$ & Number of cherries perforated by CBB with BB & \multirow{2}{*}{$(b / B) \times 100$} \\
\hline & $B$ & Total number of cherries perforated by CBB & \\
\hline
\end{tabular}

\subsubsection{Determination of Shade Percentage}

Shade $\%$ was calculated with the following formula for each of the 76 coffee plants assessed: shade $\%=(1-$ (average $\mathrm{W}$ under shade $/ \mathrm{W}$ in shade-free $)) \times(100)$. This was used to calculate the mean shade percentage per zone. The weighted average shade $\%$ of the plot was estimated as: $[(($ average shade percentage of SUN $) \times($ net area percentage of SUN $))+$ $\left(\left(\right.\right.$ average shade percentage of $\left.\mathrm{MB}_{1.95}\right) \times\left(\right.$ net area percentage of $\left.\left.\mathrm{MB}_{1.95}\right)\right)+\ldots+(($ average shade percentage of $\left.\mathrm{MB}_{7.60} \mathrm{ES}_{4.67}\right) \times\left(\right.$ net area percentage of $\left.\left.\left.\mathrm{MB}_{7.60} \mathrm{ES}_{4.67}\right)\right)\right] \times(100)$ for each period of time referred to in Section 2.4.

The daily average shade $\%$ of the plot was estimated by taking the mean of the weighted average shade $\%$ of each time slot.

\subsection{Statistical Analysis}

Data were analyzed in Minitab ${ }^{\circledR} 18$ (State College, PA, USA) [51], using mixed linear models for a split-plot design with 3 repetitions, treatments as fixed effects, blocks as random effects, and including the interaction term. Tukey's test was used for multiple comparisons with a significance level of $\alpha=0.05$. Residual normality checks of homogeneity of variance were done prior to analysis and log-transformed, if required. For the shade $\%$ data, if the homogeneity variance criterion was not fulfilled, the Friedman non-parametric test was applied to illustrate a difference between the treatments. To compare the average shade \% of the 3 periods in a day, the same RCBD was applied, the 3 factors being the shading method, the period in a day, and the block. 


\section{Results}

No significant interactions were detected between shading and farming practices. IO and LO farming practices had a lower mean CBB infestation than the IC farming practice in September only with no significant differences on other dates (Figure 2).

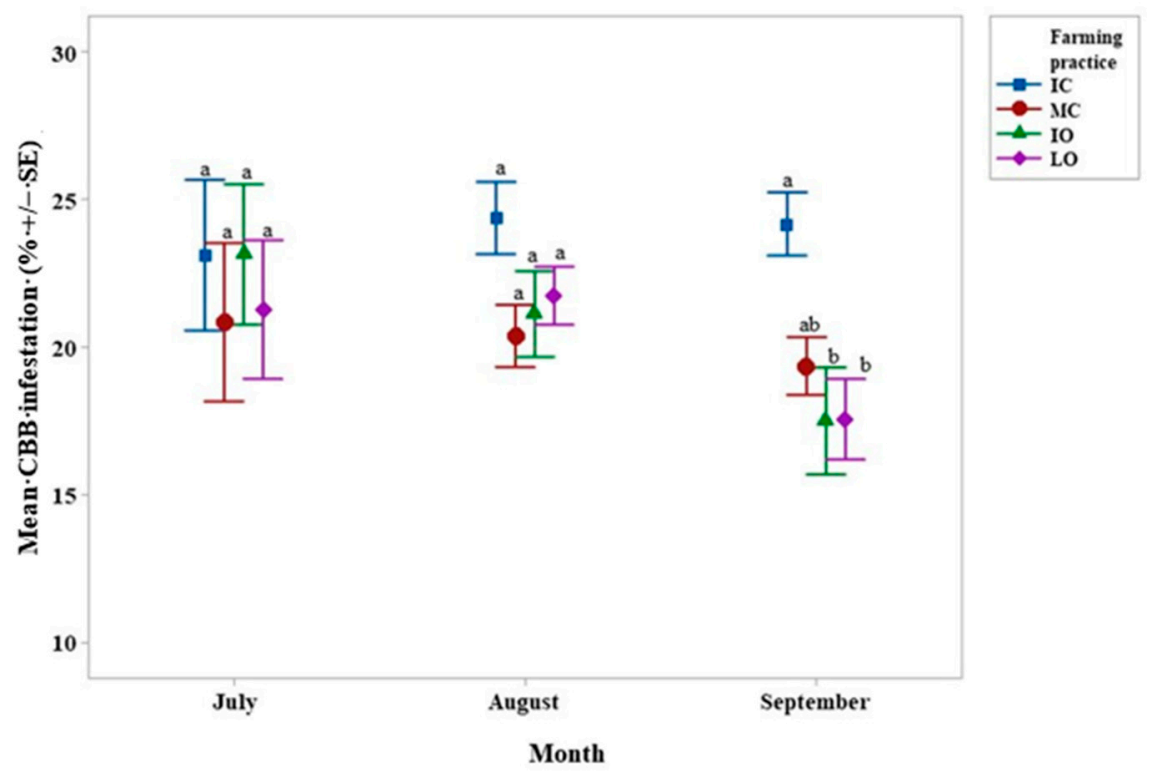

Figure 2. Interval plot of the mean Hypothenemus hampei (CBB) infestation (\%) according to the month and the farming practice. Values labeled with the same letter are not significantly different at $p=0.05$. Lines denote 1 s.e. mean. IC = intensive conventional, $\mathrm{MC}=$ moderate conventional, $\mathrm{IO}=$ intensive organic, $\mathrm{LO}=$ low organic.

The IC treatment had a BTB infestation $7 \%$ higher $(p<0.01)$ than the IO farming practice, and $6 \%$ higher $(p<0.01)$ than the LO farming practice in July (Figure 3$)$. In July only, the MC treatment had a mean BTB infestation $5 \%$ higher $(p<0.05)$ than the IO farming practice in July only. All other differences were insignificant. The SUN treatment had a BTB infestation 5\% higher $(p<0.05)$ than the GUA shade treatment in July only. All other differences were insignificant. Over all treatments, mean BTB infestation decreased over time.

LO and IO farming practices presented a markedly lower mean BB presence than the IC and MC farming practices for both July and September (Figure 4). According to Tukey's post-hoc tests, MC farming practice had a mean BB presence 3 times higher $(p<0.01)$ than the LO farming practice in July. In September, the IC farming practice had a mean BB presence $10 \%$ higher $(p<0.01)$ than the IO farming practice, and $9 \%$ higher $(p<0.05)$ than the LO farming practice. In addition, the MC farming practice had a mean BB presence $9 \%$ higher $(p<0.01)$ than the IO farming practice and $8 \%$ higher $(p<0.05)$ than the LO farming practice. In August, there were no significant differences between the treatments.

In July, the IO farming practice had a mean $\mathrm{AD}$ severity $1.57 \%$ higher $(p<0.05)$ than the IC farming practice, in addition to a mean AD severity $1.22 \%$ higher $(p<0.05)$ than the LO farming practice (Figure 5), whereas the IO practice was not significantly different from the MC practice. 

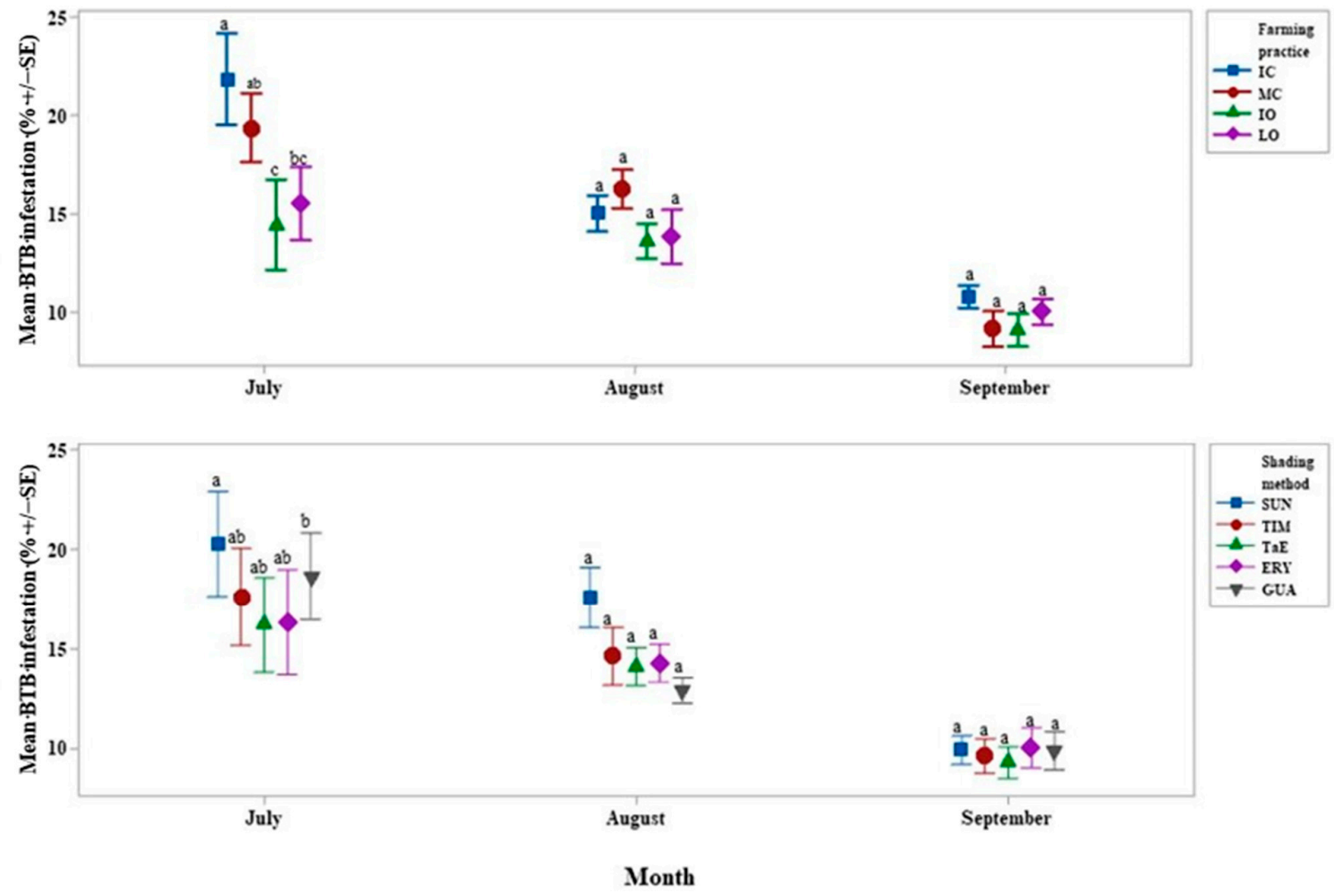

Figure 3. Interval plot of the mean Xylosandrus morigerus (BTB) infestation (\%) according to the month and the farming practice (above) or the shading method (below). Values labeled with the same letter are not significantly different at $p=0.05$. Lines denote 1 s.e. mean. IC = intensive conventional, $\mathrm{MC}=$ moderate conventional, $\mathrm{IO}=$ intensive organic, $\mathrm{LO}=$ low organic, SUN = full sun, TIM = Myroxylon balsamum and Musa spp., TaE = Myroxylon balsamum, Erythrina spp. and Musa spp., ERY = Erythrina spp. and Musa spp., GUA = Inga edulis and Musa spp.

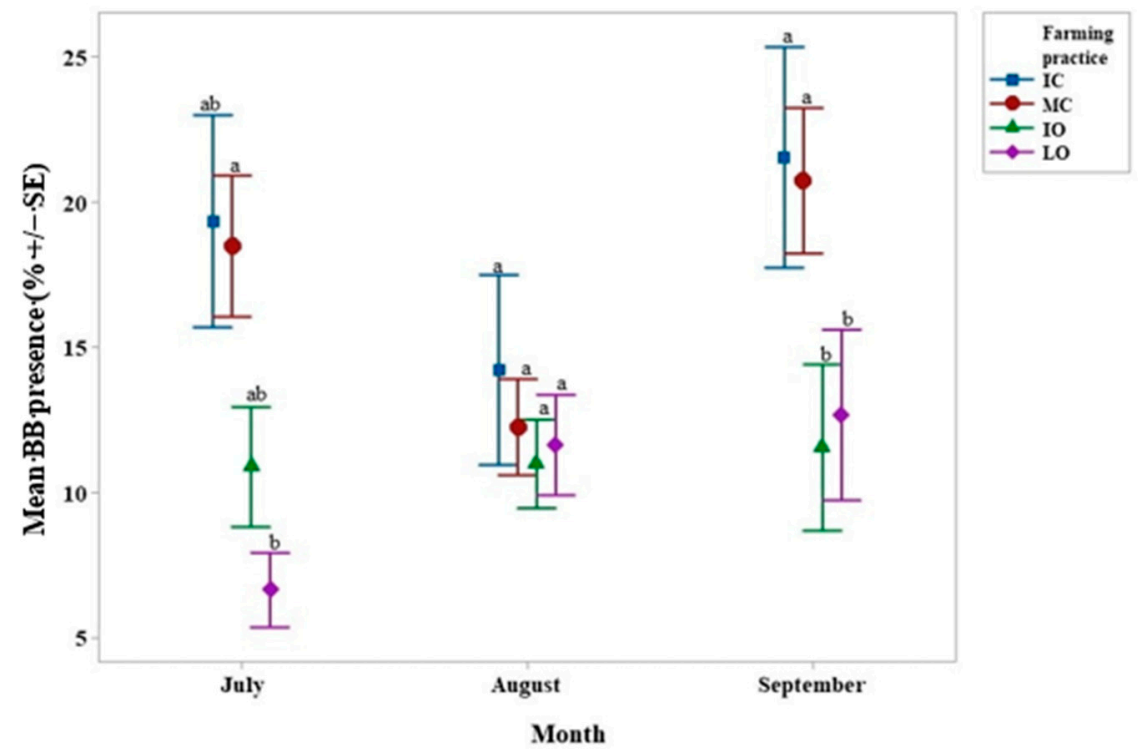

Figure 4. Interval plot of the mean Beauveria bassiana (BB) presence (\%) according to the month and the farming practice. Values labeled with the same letter are not significantly different at $p=0.05$. Lines denote 1 s.e. mean. IC = intensive conventional, $\mathrm{MC}=$ moderate conventional, $\mathrm{IO}=$ intensive organic, LO = low organic. 


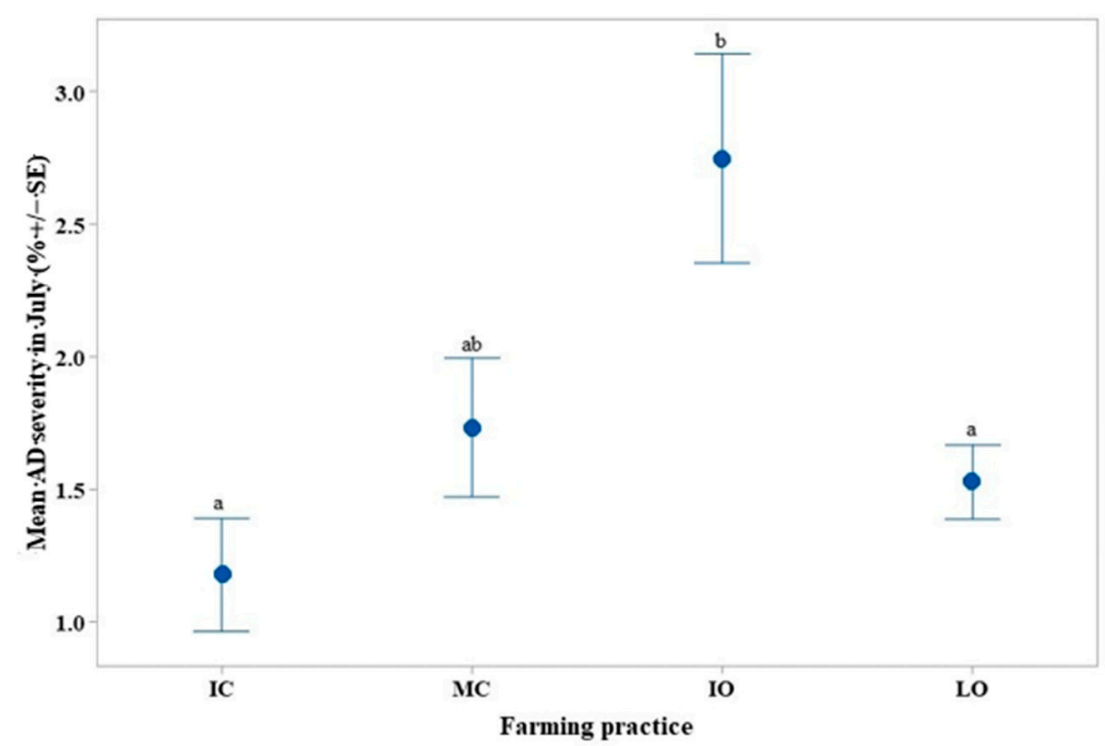

Figure 5. Interval plot of the mean Colletotrichum spp. (AD) severity (\%) according to the farming practice in July 2018. Values labeled with the same letter are not significantly different at $p=0.05$. Lines denote 1 s.e. mean. IC = intensive conventional, $\mathrm{MC}=$ moderate conventional, $\mathrm{IO}=$ intensive organic, $\mathrm{LO}=$ low organic.

The interval plot shown in Figure 6 gathers the overall means for each month of all response variables without any significant results. The mean AD incidence, the mean CLM infestation, and the mean CLS incidence were the lowest in September. Nevertheless, the mean AD incidence increased from July to August and decreased markedly from August to September.

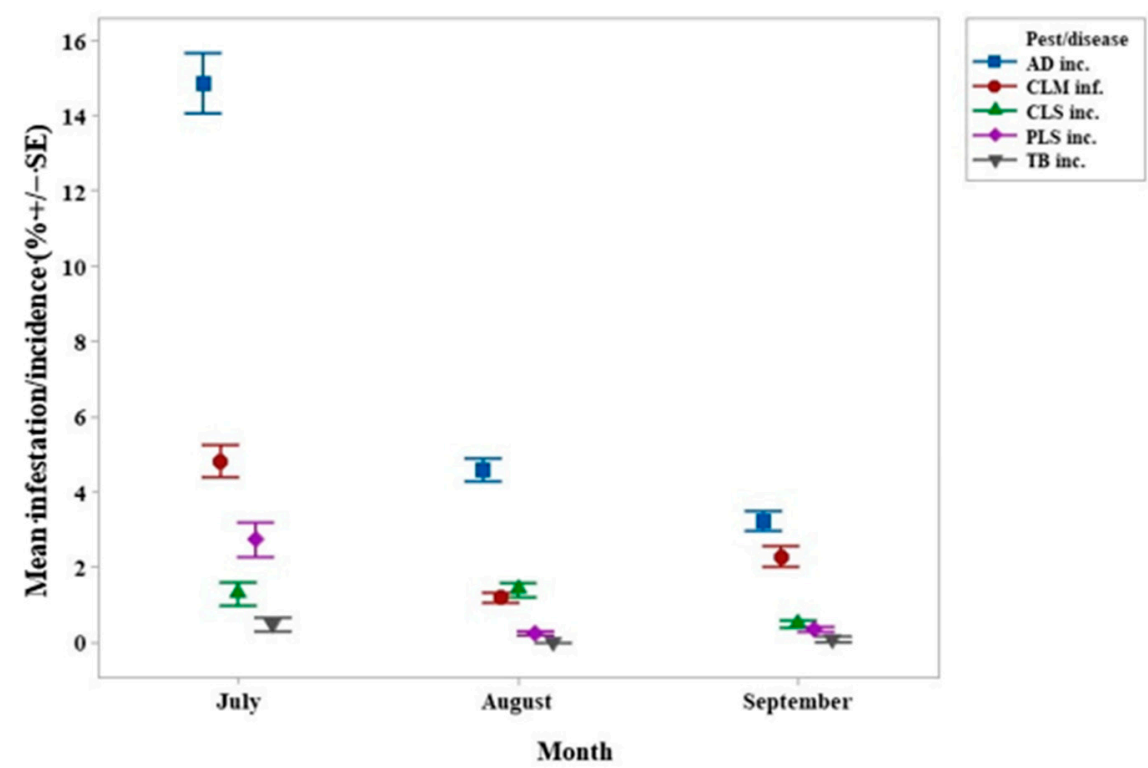

Figure 6. Interval plot of the overall mean Colletotrichum spp. incidence (AD inc.), Leucoptera coffeella infestation (CLM inf.), Cercospora coffeicola incidence (CLS inc.), Phoma spp. incidence (PLS inc.), and Pellicularia koleroga incidence (TB inc.) in July, August, and September 2018. Lines denote 1 s.e. mean.

Mean daily shade percentages of the plots applying the SUN, TaE, TIM, GUA, and ERY shading methods were $0.6 \%, 9.2 \%, 15.1 \%, 26.4 \%$, and $29.8 \%$, respectively (Figure S4). The temporary Musa spp. shade is included in the shade percentages achieved. In fact, along with the TIM shading method, the bananas were the main contributors to shade at 
this early stage in the plot. The same tendency appears in the TaE shading method, where the density of MB trees is 41 plants/ha, whereas it is 83 plants/ha in the TIM shading method. In the TaE shading method, MB trees could not provide so much shade due to the low density, low height, and crown diameter. As to the ES trees within TaE plots, the shade they provided accounted for about 3.7\%, and the ERY shading method counted about 333 plants / ha for a $29.8 \%$ shade percentage, also meaning that the shade provided by banana trees can be estimated as between $5.5 \%$ and $15.1 \%$.

\section{Discussion}

\subsection{Hypothenemus Hampei Infestation-Beauveria Bassiana Presence}

The most compelling effect of the farming practices was on CBB infestation and BB presence in September, which were positively correlated. CBB infestation was much greater in the IC treatment than in the others and BB was much greater in the two conventional treatments (Figures 2 and 4). Similar results have been found in an arabica coffee plantation in Nicaragua where organic and integrated farm managements allowed the reduction of the CBB adult population [52]. Herbicide use was highest in the IC treatment (K. Piato, pers. obs.). As certain weeds such as Lantana camara, a common weed in coffee fields [53], can repel CBB, this might explain the lower CBB infestation in the less intensive treatments. Weed removal can reduce ant populations, which are natural enemies of $\mathrm{CBB}$, thus inadvertently increasing infestation [54]. Seven or more ant genera can prey on infested berries and can reduce CBB infestation by up to $27 \%$ [55-57]. It is crucial to retain complex vegetation within agroecosystems, providing habitats for several ant genera. For instance, the CBB predator, Pheidole synanthropica, nests on the ground, whereas the CBB predator Azteca sp. needs trees to nest and forage [58].

$\mathrm{CBB}$ and BB infestation were also positively correlated $(p<0.05$ in August and $p<0.01$ in September). Similar correlations have been found in Mexico [59]. This could explain why significantly less BB was found in CBB-infested fruits in organic treatments (IO or LO) than in conventional ones (IC and MC). Rain splash dispersal may be more pronounced in conventional plots, due to less weed cover, and this could explain why BB was more widespread, as shown elsewhere [60,61]. Pohlan et al. [62] showed that cover crops can reduce $\mathrm{CBB}$ populations, since they provide habitats for natural enemies. This hypothesis could explain why there were more $\mathrm{CBB}$, and therefore associated $\mathrm{BB}$, under conventional treatments, whereas the contrary could have been expected [63]. Moreover, cultivation generally does not seem to affect the level of the presence of BB in soils, whether natural or cultivated [64].

Unlike in previous studies [23,29], the CBB infestation was not impacted by shade most probably because the shade was not uniformly distributed within the plots. There were zones within the plots subject to direct sunlight despite the presence of shelter trees. Small sun-exposed patches could favor CBB activity owing to the higher temperature there [65].

\subsection{Xylosandrus Morigerus Infestation}

The BTB and other Xylosandrus spp. preferably attack weak coffee plants lacking fertilization, since fertilization reduces the development of ambrosia fungus, associated with BTB feeding [66,67]. Herbicide use in IC and MC practices, through reducing weed biomass, may have reduced natural enemies, especially BB and ants of Crematogaster, Leptothorax, Pheidole, Pseudomyrmex, and Solenopsis genera [67]. In particularly, a field cage trial performed with robusta coffee twigs showed that Pheidole megacephala, commonly found in both the tropics and subtropics, preys on all life stages of X. compactus [68]. Many coffee weeds are BTB host plants, notably Verbena littoralis, which is found in Ecuador [69]. Removing weeds might have increased BTB infestation, as it is no longer diluted among alternative hosts.

A reduction in $X$. compactus infestation with shade was demonstrated in Uganda [25]. However, in our study, the ERY treatment had higher shade yet BTB infestation was not different from that in the shade-free control. Alternatively, as IE is a host for BTB [69], it 
also might attract BTB, reducing its impact on robusta coffee plants. Further research is needed to firmly corroborate this hypothesis.

\subsection{Colletotrichum spp. (AD) Incidence and Severity}

AD spreads through water-borne conidia, maximum growth occurring at $\mathrm{pH}$ 6.57.0 and $25{ }^{\circ} \mathrm{C}-30{ }^{\circ} \mathrm{C}$; conidia germinate at $95 \%-100 \%$ relative humidity (RH) [70-72]. In mid-July, $\mathrm{AD}$ incidence was high (Figure 6), due to a favorable climate for fungus in June, with $\mathrm{RH}$ of $95 \%$ at 7 am allowing the conidia to germinate (Table 1). In June, the mean maximum temperature did not exceed $30^{\circ} \mathrm{C}$, another factor contributing to a better growth of $\mathrm{AD}$. AD incidence decreased significantly in August (Figure 6), after the mean maximum temperature had exceeded $30^{\circ} \mathrm{C}$ in July and RH remained above $95 \%$ (Table 1). The decrease continued in September, after the temperature had exceeded $30{ }^{\circ} \mathrm{C}$ in August, when it rained less $(150.7 \mathrm{~mm})$ and the RH decreased so these changes may explain the lower AD incidence in September (Table 1). The impact of shade treatment on AD was not significant, whereas AD had the highest severity in the IO treatment with other farming practices being variable.

\subsection{Shade Percentages}

CBB infestation responds to shade levels $>25 \%$ [29]. As coffee plants were at the sapling stage, they did not provide self-shading, and the MB trees had been pruned and were slow growing. Therefore, $\mathrm{MB}$ trees did not contribute much to the shade $\%$ so plantains were the main shade providers. Plantains provided varying amounts of shade depending on height and leaf number. However, given a quadrupled tree density, the ERY shading method had the highest shade \% (30\%). Nevertheless, the IE shading method with almost the same shade \% as the ERY one could be more practical for farmers. Using it would reduce pruning requirements, as the tree density of IE shading method is half as high as for the ERY one. Additionally, according to on-site observations, no shelter trees suffered from pest or disease damage to a degree able to reduce substantially the shade amount.

\section{Conclusions}

In young coffee farms under different shade and farming practices, infestation rates of the coffee berry borer and the brown twig beetle were significantly and up to $7 \%$ higher when more intensive and conventional practices were applied, compared with organic practices at the same input level or lower intensity. The presence of the entomopathogen Beauveria bassiana was higher in the conventional intensive plots but this was probably related to the higher infestation of the pests. Brown twig beetle infestation was also higher in shade-free conditions; yet on the contrary, shade-free conditions reduced anthracnose severity, albeit only marginally $(<2 \%)$. This highlights a trade-off between pest and disease damage when comparing shaded and unshaded conditions although the reduction in pest infestation with shading was greater than the increase in fungal diseases. While this study demonstrates pest and disease dynamics at an early stage in the plantation life, it highlights that intensified conventional input use, while potentially leading to high plant productivity, might promote pest populations and thus ultimately lead to greater yield losses.

Supplementary Materials: The following materials are available online at https: / www.mdpi.com/ article/10.3390/life11050413/s1, Figure S1: Rainfall per year (mm) from 2010 to 2017 in La Joya de los Sachas, Orellana, Ecuador. Figure S2: Max. temperature per year $\left({ }^{\circ} \mathrm{C}\right)$ from 2010 to 2017 in La Joya de los Sachas, Orellana, Ecuador. Figure S3: Min temperature per year $\left({ }^{\circ} \mathrm{C}\right)$ from 2010 to 2017 in La Joya de los Sachas, Orellana, Ecuador. Figure S4: Box and whisker plots of the 2018 mean shade (\%) in relation to the shading method. Table S1: Weeding schedule in 2017 and 2018 for IC, MC, IO and LO farming practices with herbicide rates $\left(\mathrm{L} \mathrm{ha}^{-1}\right)$ in parentheses. Table S2: Defined zones with homogeneous shade, according to distance from coffee plants to shelter trees. 
Author Contributions: Conceptualization, K.P., F.L, C.S., J.P., and D.C; methodology, K.P., F.L, C.S., J.P., and D.C; investigation, K.P., C.S., J.P., and D.C.; formal analysis, K.P., C.S., F.L., and L.N.; writingoriginal draft preparation, K.P., F.L., and L.N.; writing-review and editing, K.P., F.L., and L.N.; validation, F.L. and L.N.; supervision, C.S., F.L.; data curation, K.P., F.L., and L.N.; resources, C.S., F.L., C.S., J.P., and D.C. All authors have read and agreed to the published version of the manuscript.

Funding: This work was supported by HEPIA (Geneva School of Engineering, Architecture, and Landscape, HES-SO University of Applied Sciences, and Arts Western Switzerland) and INIAP.

Institutional Review Board Statement: Not applicable.

Informed Consent Statement: Not applicable.

Data Availability Statement: The data presented in this study are available on request from the corresponding author.

Acknowledgments: The authors are grateful to the staff of INIAP/EECA for its scientific and technical support.

Conflicts of Interest: The authors declare no conflict of interest.

\section{References}

1. Bunn, C.; Läderach, P.; Ovalle Rivera, O.; Kirschke, D. A bitter cup: Climate change profile of global production of Arabica and Robusta coffee. Clim. Chang. 2015, 129, 89-101. [CrossRef]

2. DaMatta, F.M.; Ramalho, J.D.C. Impacts of drought and temperature stress on coffee physiology and production: A review. Braz. J. Plant Physiol. 2006, 18, 55-81. [CrossRef]

3. Ovalle-Rivera, O.; Läderach, P.; Bunn, C.; Obersteiner, M.; Schroth, G. Projected shifts in Coffea arabica suitability among major global producing regions due to climate change. PLoS ONE 2015, 10, e0124155. [CrossRef] [PubMed]

4. Flores, M.; Bratescu, A.; Martínez, J.O.; Oviedo, J.A.; Acosta, A. Centroamérica: El Impacto de la Caída de los Precios del Café; Naciones Unidas Comisión Económica para América Latina y el Caribe (CEPAL): Ciudad de México, Mexico, 2002; ISBN 92-1-322015-4.

5. ICO. Sustainability of the coffee sector in Africa. In 114th International Coffee Council: London, 2-6 March 2015; International Coffee Organization (ICO): London, UK, 2015.

6. Jácome, A.R.; Garrido, A. A Real Option Analysis applied to the production of Arabica and Robusta Coffee in Ecuador. Span. J. Agric. Res. 2017, 15, e0104. [CrossRef]

7. Jaramillo, J.; Muchugu, E.; Vega, F.E.; Davis, A.; Borgemeister, C.; Chabi-Olaye, A. Some like it hot: The influence and implications of climate change on coffee berry borer (Hypothenemus hampei) and coffee production in East Africa. PLoS ONE 2011, 6, e24528. [CrossRef] [PubMed]

8. Waller, J.M.; Bigger, M.; Hillocks, R.J. Coffee Pests, Diseases and Their Management; CABI Pub: Wallingford, UK; Cambridge, MA, USA, 2007; ISBN 978-1-84593-129-2.

9. Staver, C.; Guharay, F.; Monterroso, D.; Muschler, R.G. Designing pest-suppressive multistrata perennial crop systems: Shadegrown coffee in Central America. Agrofor. Syst. 2001, 53, 151-170. [CrossRef]

10. Beer, J. Advantages, disadvantages and desirable characteristics of shade trees for coffee, cacao and tea. Agrofor. Syst. 1987, 5, 3-13. [CrossRef]

11. Tscharntke, T.; Clough, Y.; Bhagwat, S.A.; Buchori, D.; Faust, H.; Hertel, D.; Hölscher, D.; Juhrbandt, J.; Kessler, M.; Perfecto, I.; et al. Multifunctional shade-tree management in tropical agroforestry landscapes-A review. J. Appl. Ecol. 2011, 48, 619-629. [CrossRef]

12. Alves, V.; Goulart, F.F.; Jacobson, T.K.B.; Filho, R.J.d.M.; Ribas, C.E.D.C. Shade's Benefit: Coffee Production under Shade and Full Sun. J. Agric. Sci. 2016, 8, 11-19. [CrossRef]

13. Nutman, F.J. Studies of the Physiology of Coffea arabica: I. Photosynthesis of Coffee Leaves under Natural Conditions. Ann. Bot. 1937, 1, 353-367. [CrossRef]

14. Nutman, F.J. Studies of the Physiology of Coffea arabica: II. Stomatal Movements in Relation to Photosynthesis under Natural Conditions. Ann. Bot. 1937, 1, 681-693. [CrossRef]

15. Bedimo, J.A.M.; Dufour, B.P.; Cilas, C.; Avelino, J. Effets des arbres d'ombrage sur les bioagresseurs de Coffea arabica. Cah. Agric. 2012, 21, 89-97. [CrossRef]

16. Schroth, G.; Krauss, U.; Gasparotto, L.; Duarte Aguilar, J.A.; Vohland, K. Pests and diseases in agroforestry systems of the humid tropics. Agrofor. Syst. 2000, 50, 199-241. [CrossRef]

17. Barradas, V.L.; Fanjul, L. Microclimatic chacterization of shaded and open-grown coffee (Coffea arabica L.) plantations in Mexico. Agric. For. Meteorol. 1986, 38, 101-112. [CrossRef]

18. Beer, J.; Muschler, R.; Kass, D.; Somarriba, E. Shade management in coffee and cacao plantations. Agrofor. Syst. 1998, 38, 139-164. [CrossRef]

19. Piato, K.; Lefort, F.; Subía, C.; Caicedo, C.; Calderón, D.; Pico, J.; Norgrove, L. Effects of shade trees on robusta coffee growth, yield and quality. A meta-analysis. Agron. Sustain. Dev. 2020, 40, 1-13. [CrossRef] 
20. Davis, A.P.; Govaerts, R.; Bridson, D.M.; Stoffelen, P. An annotated taxonomic conspectus of the genus Coffea (Rubiaceae). Bot. J. Linn. Soc. 2006, 152, 465-512. [CrossRef]

21. Snoeck, J.; Lambot, C. Crop maintenance. In Coffee: Growing, Processing, Sustainable Production; Wintgens, J.N., Ed.; Wiley-VCH Verlag GmbH: Weinheim, Germany, 2004; pp. 251-327; ISBN 9783527619627.

22. Cerda, R.; Allinne, C.; Gary, C.; Tixier, P.; Harvey, C.A.; Krolczyk, L.; Mathiot, C.; Clément, E.; Aubertot, J.-N.; Avelino, J. Effects of shade, altitude and management on multiple ecosystem services in coffee agroecosystems. Eur. J. Agron. 2017, 82, 308-319. [CrossRef]

23. Jonsson, M.; Raphael, I.A.; Ekbom, B.; Kyamanywa, S.; Karungi, J. Contrasting effects of shade level and altitude on two important coffee pests. J. Pest Sci. 2015, 88, 281-287. [CrossRef]

24. Nesper, M.; Kueffer, C.; Krishnan, S.; Kushalappa, C.G.; Ghazoul, J. Shade tree diversity enhances coffee production and quality in agroforestry systems in the Western Ghats. Agric. Ecosyst. Environ. 2017, 247, 172-181. [CrossRef]

25. Bukomeko, H.; Jassogne, L.; Kagezi, G.H.; Mukasa, D.; Vaast, P. Influence of shaded systems on Xylosandrus compactus infestation in Robusta coffee along a rainfall gradient in Uganda. Agric. For. Entomol. 2018, 20, 327-333. [CrossRef]

26. Mariño, Y.A.; Vega, V.J.; García, J.M.; Verle Rodrigues, J.C.; García, N.M.; Bayman, P. The Coffee Berry Borer (Coleoptera: Curculionidae) in Puerto Rico: Distribution, Infestation, and Population per Fruit. J. Insect Sci. 2017, 17, 1-8. [CrossRef] [PubMed]

27. Silva, M.G.; Pozza, E.A.; Vasco, G.B.; Freitas, A.S.; Chaves, E.; Paula, P.V.A.A.; Dornelas, G.A.; Alves, M.C.; Silva, M.L.O.; Pozza, A.A.A. Geostatistical analysis of coffee leaf rust in irrigated crops and its relation to plant nutrition and soil fertility. Phytoparasitica 2019, 47, 117-134. [CrossRef]

28. Avelino, J.; Willocquet, L.; Savary, S. Effects of crop management patterns on coffee rust epidemics. Plant Pathol. 2004, 53, 541-547. [CrossRef]

29. Atallah, S.S.; Gómez, M.I.; Jaramillo, J. A Bioeconomic Model of Ecosystem Services Provision: Coffee Berry Borer and Shadegrown Coffee in Colombia. Ecol. Econ. 2018, 144, 129-138. [CrossRef]

30. ICO. Domestic Consumption by All Exporting Countries. Available online: http://www.ico.org/historical/1990\%20onwards/ PDF/1b-domestic-consumption.pdf (accessed on 19 August 2019).

31. Nieto, C.; Caicedo, C.E.V. Sistemas de Producción Agropecuarios de la Región Amazónica Ecuatoriana RAE: Análisis Reflexivo y Propositivo Sobre las Potencialidades. In Agroforestería Sostenible en la Amazonía Ecuatoriana; de Melo, E.V.F., Caicedo, C.E.V., Astorga, C.D., Eds.; CATIE (Centro Agronómico Tropical de Investigación y Enseñanza): Turrialba, Costa Rica, 2014 ; pp. 25-34. ISBN 978-9977-57-623-7.

32. Barrance, A.; Beer, J.; Boshier, D.H.; Chamberlain, J.; Cordero, J.; Detlefsen, G.; Finegan, B.; Galloway, G.; Gómez, M.; Gordon, J.; et al. Inga edulis Mart. In Árboles de Centroamérica: Un Manual Para Extensionistas; Cordero, J., Ed.; CATIE: Turrialba, Costa Rica, 2003; pp. 605-606. ISBN 0850741610.

33. Stamps, W.T.; Linit, M.J. Plant diversity and arthropod communities: Implications for temperate agroforestry. Agrofor. Syst. 1997, 39, 73-89. [CrossRef]

34. Augspurger, C.K. Seedling Survival of Tropical Tree Species: Interactions of Dispersal Distance, Light-Gaps, and Pathogens. Ecology 1984, 65, 1705-1712. [CrossRef]

35. Sartori, Â.L.B.; Lewis, G.P.; de Freitas Mansano, V.; de Azevedo Tozzi, A.M. A revision of the genus Myroxylon (Leguminosae: Papilionoideae). Kew Bull. 2015, 70, 48. [CrossRef]

36. Valencia, R.; Balslev, H.; Paz, Y.; Miño, C.G. High tree alpha-diversity in Amazonian Ecuador. Biodivers. Conserv. 1994, 3, 21-28. [CrossRef]

37. Pereira, R.; de Souza, E.B.; Fontenelle, R.O.d.S.; de Vasconcelos, M.A.; Santos, H.S.d.; Teixeira, E.H. Diversidade estrutural e potencial biológico dos metabólitos secundários de espécies do gênero Myroxylon L.f. (Fabaceae): Uma revisão da literatura. Hoehnea 2019, 46, e582017. [CrossRef]

38. Kass, D.L. Erythrina species: Pantropical multipurpose tree legumes. In Forage Tree Legumes in Tropical Agriculture; Gutteridge, R.C., Shelton, H.M., Eds.; CAB International: Wallingford, UK, 1994; pp. 84-96. ISBN 0851988687.

39. Boreux, V.; Vaast, P.; Madappa, L.P.; Cheppudira, K.G.; Garcia, C.; Ghazoul, J. Agroforestry coffee production increased by native shade trees, irrigation, and liming. Agron. Sustain. Dev. 2016, 36, 42. [CrossRef]

40. Peel, M.C.; Finlayson, B.L.; McMahon, T.A. Updated world map of the Köppen-Geiger climate classification. Hydrol. Earth Syst. Sci. 2007, 11, 1633-1644. [CrossRef]

41. INAMHI. Mapa de Precipitación Media Multianual: Serie 1965-1999. Available online: http:/ / www.serviciometeorologico.gob. ec/docum_institucion/MapasBiblioteca/5\%20PrecipitacionA0.pdf (accessed on 19 August 2019).

42. INAMHI. Mapa de Temperatura Media Multianual: Serie 1965-1999. Available online: http:/ /www.serviciometeorologico.gob. ec/docum_institucion/MapasBiblioteca/6\%20TemperaturaA0.pdf (accessed on 19 August 2019).

43. Soil Survey Staff. Keys to Soil Taxonomy, 12th ed.; United States Department of Agriculture (USDA), Natural Resources Conservation Service (NRCS): Washington, DC, USA, 2014; ISBN 9780359573240.

44. Holdridge, L.R.; Tosi, J.A. Life Zone Ecology; Tropical Science Center: San Jose, CA, USA, 1967.

45. INAMHI. Datos Meteorológicos de la EECA en Joya de los Sachas; EECA; Instituto Nacional de Meteorología e Hidrología (INAMHI): Quito, Ecuador, 2018.

46. World Weather Online. La Joya De Los Sachas Monthly Climate Averages. Available online: https:/ / www.worldweatheronline. com/la-joya-de-los-sachas-weather-averages/orellana/ec.aspx (accessed on 18 April 2021). 
47. Compendium of Coffee Diseases and Pests; Gaitán, A.L. (Ed.) APS Press: St. Paul, MN, USA, 2016; ISBN 0890544727.

48. Avelino, J.; Muller, R.A.; Cilas, C.; Velasco, H.P. Développement et comportement de la rouille orangée du caféier (Hemileia vastatrix Berk. et Br.) dans des plantations en cours de modernisation, plantées de variétés naines, dans le sud-est du Mexique (Francés traducido integralmente al Español)_Desarrollo y comportamiento de la roya anaranjada del cafeto (Hemileia vastatrix Berk. y Br.) en plantaciones en proceso de modernización, cultivadas con variedades de porte bajo en el Sureste de México. Cafe Cacao The 1991, 35, 21-37.

49. Van Long, N.; Ngoc, N.Q.; Dung, N.N.; Kristiansen, P.; Yunusa, I.; Fyfe, C. The Effects of Shade Tree Types on Light Variation and Robusta Coffee Production in Vietnam. Engineering 2015, 7, 742-753. [CrossRef]

50. Wayne Rasband. ImageJ; National Institutes of Health: Bethesda, MD, USA, 2018.

51. Minitab, L.L. Minitab®18 Statistical Software; Minitab L.L.: State College, PA, USA, 2018.

52. Bagny Beilhe, L.; Roudine, S.; Quintero Perez, J.A.; Allinne, C.; Daout, D.; Mauxion, R.; Carval, D. Pest-regulating networks of the coffee berry borer (Hypothenemus hampei) in agroforestry systems. Crop. Prot. 2020, 131, 105036. [CrossRef]

53. Castro, A.M.; Tapias, J.; Ortiz, A.; Benavides, P.; Góngora, C.E. Identification of attractant and repellent plants to coffee berry borer, Hypothenemus Hampei. Entomol. Exp. Appl. 2017, 164, 120-130. [CrossRef]

54. Philpott, S.M.; Armbrecht, I. Biodiversity in tropical agroforests and the ecological role of ants and ant diversity in predatory function. Ecol. Entomol. 2006, 31, 369-377. [CrossRef]

55. Armbrecht, I.; Gallego, M.C. Testing ant predation on the coffee berry borer in shaded and sun coffee plantations in Colombia. Entomol. Exp. Appl. 2007, 124, 261-267. [CrossRef]

56. Bustillo, A.E.; Cárdenas, R.; Posada, F. Natural Enemies and Competitors of Hypothenemus hampei (Ferrari) (Coleoptera: Scolytidae) in Colombia. Neotrop. Entomol. 2002, 31, 635-639. [CrossRef]

57. Morris, M.D.; Jiménez-Soto, E.; Philpott, S.M.; Perfecto, I. Ant-mediated (Hymenoptera: Formicidae) biological control of the coffee berry borer: Diversity, ecological complexity, and conservation biocontrol. Myrmecol. News 2018, 26, 1-17.

58. Perfecto, I.; Vandermeer, J.H. Coffee Agroecology: A New Approach to Understanding Agricultural Biodiversity, Ecosystem Services and Sustainable Development; Routledge, Eartscan: Abingdon, NY, USA, 2015; ISBN 978-0-415-82681-5.

59. De La Rosa, W.; Alatorre, R.; Barrera, J.F.; Toreillo, C. Effect of Beauveria bassiana and Metarhizium anisopliae (Deuteromycetes) upon the coffee berry borer (Coleoptera: Scolytidae) under field conditions. J. Econ. Entomol. 2000, 93, 1409-1414. [CrossRef] [PubMed]

60. Bruck, D.J.; Lewis, L.C. Rainfall and crop residue effects on soil dispersion and Beauveria bassiana spread to corn. Appl. Soil Ecol. 2002, 20, 183-190. [CrossRef]

61. Bruck, D.J. Dynamics of the fungus Beauveria bassiana. In Retrospective Theses and Dissertations; Iowa State University: Ames, IA, USA, 2001. [CrossRef]

62. Pohlan, H.A.J.; Janssens, M.J.; Eversbusch, B.G. Impact of Canavalia Cover Crop Management in Coffea arabica L. on PlantInvertebrate Associations. Open Agric. J. 2008, 2, 84-89. [CrossRef]

63. Soares, F.B.; Monteiro, A.C.; Babosa, J.C.; Mochi, D.A. Population density of Beauveria bassiana in soil under the action of fungicides and native microbial populations. Acta Sci. Agron. 2017, 39, 465. [CrossRef]

64. Quesada-Moraga, E.; Navas-Cortés, J.A.; Maranhao, E.A.A.; Ortiz-Urquiza, A.; Santiago-Alvarez, C. Factors affecting the occurrence and distribution of entomopathogenic fungi in natural and cultivated soils. Mycol. Res. 2007, 111, 947-966. [CrossRef]

65. Constantino, L.M.; Gil, Z.N.; Montoya, E.C.; Benavides, P. Coffee Berry Borer (Hypothenemus hampei) Emergence from Ground Fruits Across Varying Altitudes and Climate Cycles, and the Effect on Coffee Tree Infestation. Neotrop. Entomol. 2021. Epub ahead of print. [CrossRef]

66. Greco, E.B.; Wright, M.G. Ecology, Biology, and Management of Xylosandrus compactus (Coleoptera: Curculionidae: Scolytinae) with Emphasis on Coffee in Hawaii. J. Integr. Pest Manag. 2015, 6, 7. [CrossRef]

67. Jaramillo, M.G.; Benavides, P.; Constantino, L. Conozca al Pasador de las Ramas del Café Xylosandrus Morigerus (Coleoptera: Curculionidae: Scolytinae); Avances Técnicos No. 460; Centro Nacional de Investigationes de Café - Cenicafé: Manizales, Caldas, Colombia, 2015.

68. Ogogol, R.; Egonyu, J.P.; Bwogi, G.; Kyamanywa, S.; Erbaugh, M. Interaction of the predatory ant Pheidole megacephala (Hymenoptera: Formicidae) with the polyphagus pest Xylosandrus compactus (Coleoptera: Curculionidea). Biol. Control. 2017, 104, 66-70. [CrossRef]

69. Benavides, M.G. El Xyleborus morigerus Blandford en Colombia. Cenicafe 1961, 12, 17-28.

70. Dodd, J.C.; Estrada, A.B.; Matcham, J.; Jeffries, P.; Jeger, M.J. The effect of climatic factors on Colletotrichum gloeosporioides, causal agent of mango anthracnose, in the Philippines. Plant Pathol. 1991, 40, 568-575. [CrossRef]

71. Hubballi, M.; Nakkeeran, S.; Raguchander, T.; Anand, T.; Renukadevi, P. Physiological characterisation of Colletotrichum gloeosporioides, the incitant of anthracnose disease of noni in India. Arch. Phytopathol. Plant Protect. 2011, 44, 1105-1114. [CrossRef]

72. Jeffries, P.; Dodd, J.; Jeger, M.; Plumbley, R. The biology and control of Colletotrichum species on tropical fruit crops. Plant Pathol. 1990, 39, 343-366. [CrossRef] 